\title{
AKTUALISASI IMPLEMENTASI KEBIJAKAN PENDIDIKAN PADA MADRASAH SWASTA DI SULAWESI SELATAN
}

\author{
Oleh: Abdul Rahman Halim*
}

\begin{abstract}
This research is aimed out implementation of government policy toward private Islamic schools before the role UU SPN No. 20 Year 2003. In reality, the policy of government did not run effectively, even it did not give advantages for private Islamic school, because the application is restricted to curriculum development. The Government has tried to perform several Islamic schools in order to be followed by private Islamic schools such as state Islamic schools, Islamic school for Islamic program, integrated school and so on. How ever, the Islamic private schools cannot run together with state schools because they face problem on financial and facilities of educational standard.
\end{abstract}

KEYWORDS: Policy, madrasah, quality of education

PADA awal kemerdekaan Indonesia, pemerintah dengan kebijakannya memberi perhatian dan penghargaan kepada lembaga pendidikan Islam. Hal ini terlihat dalam keputusan BP KNIP, agar madrasah berjalan terus dan dipercepat. Di samping itu, madrasah swasta sudah disetarakan dengan madrasah negeri termasuk ijazahnya, sampai lahirnya UU No. 4 Tahun 1950, disusul dengan SKB 3 Menteri, dan terakhir UU SPN No. 20 Tahun 2003. ${ }^{1}$ Demikian juga, pemerintah membantu pengembangan pendidikan Islam dengan tidak perlu merubah ciri dan identitas lembaga yang sudah melekat sejak didirikannya dan menjadi kekuatan dari madrasah itu sendiri. Meskipun dalam perjalanan madrasah terdapat diskriminasi antara madrasah negeri dan swasta, terutama terkait dengan bantuan yang sifatnya material.

Paling tidak, ada empat karakteristik madrasah yang dapat diidentifikasi, sebagai berikut:

Pertama, madrasah milik masyarakat (Community Based Education). ${ }^{2}$ Artinya, madrasah bekembang dari masyarakat dan untuk masyarakat.

*Magister Agama lulusan Universitas Muslim Indonesia ini adalah kandidat doktor dalam bidang pendidikan Islam pada Universitas Islam Negeri Sunan Kalijaga Yogyakarta. Ia adalah dosen tetap Fakultas Tarbiyah dan Keguruan UIN Alauddin Makassar. 
Oleh karena itu, dari segi kuantitas berkembang sangat pesat, meskipun dari segi kualitas perkembangannya sangat lamban.

Keterikatan masyarakat kepada madrasah lebih terlihat sebagai ikatan emosional keagamaan. Dengan kata lain, keinginan masyarakat untuk berperan serta dalam pendidikan juga didorong oleh motivasi kegamaan untuk ber-tafaqqahu fi al-din.

Kedua, madrasah sebagai manajemen berbasis sekolah (School Based Management). Keragaman dan kebebasan tidak tergantung kepada pusat dan birokrasi menjadikan madrasah banyak yang bergengsi. Konsep school based management dan community based education merupakan kenyataan tuntutan untuk memunculkan kembali kemandirian dan otonomi sekolah. Kedua hal tersebut selama ini dalam perkembangannya hilang, terhapus oleh konsep sentralisasi dan penyeragaman.

Ketiga, madrasah sebagai lembaga tafaqqahu fi al-din, agar peserta didik mempelajari dan menularkan kepada orang lain pemahaman agama baik secara formal/syar' $i$ ataupun secara fungsional. Karena itu madrasah tidak terpisahkan dengan dakwah, hanya lebih dominan pendidikan.

Keempat, madrasah sebagai lembaga kaderisasi dan mobilitas umat Islam. Dari proses pendidikan di madrasah terbentuk peribadi muslim yang saleh dengan penguasaan ilmu agama secara luas, konsisiten dan mendalam. ${ }^{3}$ Secara historis kehadiran dan perkembangan madrasah merupakan lembaga pendidikan yang lahir dari, oleh, dan untuk masyarakat. ${ }^{4}$

Kebijakan dan implementasi tidak dapat dipisahkan, sebuah kebijakan tidak berarti tanpa diimplementasikan. Carl J. Frederick menyatakan bahwa kebijakan itu adalah serangkaian tindakan seseorang, kelompok atau pemerintah dalam suatu lingkungan tertentu dengan menunjukkan hambatan-hambatan dan kesempatan-kesempatan terhadap usulan kebijakan tersebut dalam rangka mencapai tujuan tertentu. ${ }^{5}$ Kebijakan juga merupakan arah tindakan yang mempunyai maksud yang ditetapkan oleh seorang aktor dalam mengatasi suatu masalah atau suatu persoalan. ${ }^{6}$ Definisi tersebut menekankan pentinya implementasi kebijakan yang dilakukan oleh pemerintah. Dengan pengertian bahwa usaha dalam rangka implementasi kebijakan berarti melakukan pelaksanaan dan pengendalian arah tindakan kebijakan sampai dengan tercapainya hasil kebijakan.7

\section{PROSES IMPELEMNTASI KEBIJAKAN PENDIDIKAN PADA MADRA- SAH SWASTA}

Ketika lahirnya UU No. 4 Tahun 1950 jo No. 12 Tahun 1954, undangundang hanya berlaku untuk pendidikan dan pengajaran di sekolah dan tidak berlaku untuk pendidikan dan pengajaran di sekolah-sekolah agama 
dan pendidikan masyarakat. Hal ini menunjukkan bahwa perguruan agama yang dibina masyarakat tidak termasuk olahan dari undangundang ini, yang berarti pula madrasah tidak termasuk dalam sistem pendidikan nasional. Meskipun undang-undang tidak menyinggung madrasah seperti sekolah, tetapi dalam salah satu diktumnya dapat ditangkap bahwa murid yang belajar di sekolah agama yang telah diakui oleh Menteri Agama, maka mereka dianggap telah memenuhi kewajiban belajar sebagai program pemerintah.

Proses implementasi undang-undang ini melahirkan program strategik dengan dilakukannya pembaruan sistem pendidikan pada madrasah, yaitu diperkenalkannya secara resmi konsep Madrasah Wajib Belajar (MWB) oleh Menteri Agama K.H. M. Ilyas, dengan masa belajar 8 tahun. Maksud dan tujuan program MWB ini diorientasikan pada pembangunan jiwa bangsa, yaitu dengan kemajuan di bidang ekonomi, industri dan transmigrasi, sehingga kurikulum MWB diberi muatan untuk menciptakan keselarasan tiga aspek, yaitu: perkembangan otak, perkembangan hati, dan perkembangan keterampilan. Kemudian disusul dengan sebuah kebijakan berupa Peraturan Pemerintah No. 2 Tahun 1960 tentang Bantuan dan Subsidi kepada Madrasah.

Pada masa Orde Lama, seluruh kebijakan cenderung terpusat dengan kekuasaan politik yang sangat kuat. Di masa ini bantuan dan subsidi, yang sebelumnya dinikmati madrasah, ternyata sudah tidak ada, campur tangan pemerintah kepada madrasah juga sudah tidak tampak. Hal ini menyebabkan madrasah semakin ketinggalan menurut pandangan masyarakat umum.

Ketika masa Orde Baru, suasana sentralisasi dan penyeragaman (uniformisasi) makin meningkat dan lembaga pendidikan menjadi bagian dari birokrasi semakin kencang. Dari sini timbul pertimbangan dari kalangan tokoh Islam yang menuntut adanya pengakuan pemerintah serta penghargaan kepada madrasah. Pada akhirnya muncul SKB 3 Menteri yang melegitimasi pengakuan wujud kesetaraan madrasah dengan sekolah, meskipun di lapangan masih terjadi adanya diskriminasi dalam penerimaan pegawai atau mahasiswa.

Penerapan kebijakan SKB 3 Menteri Tahun 1975 (Menteri Agama, Menteri Pendidikan dan Kebudayaan, dan Menteri Dalam Negeri, No. 6 Tahun 1975, No. 037/U/1975 dan No. 36 Tahun 1975), terkait dengan mutu pendidikan pada madrasah, secara umum, mendapat tanggapan positif dari tiga organisasi yang menjadi pusat penelitian, yaitu: As'adiyah Sengkang Kabupaten Wajo, DDI Mangkoso Kabupaten Barru, dan Darul Arqam Muhammadiyah Gombara Kota Makassar. Hanya saja intensitas 
penerimaannya tentu berbeda pada setiap organisasi sesuai dengan kapasitas, potensi dan kemampuan yang dimiliki setiap organsiasi. Pada umumnya madrasah swasta melaksanakan proses pembelajaran sesuai dengan materi kurikulum SKB, dan setelah berjalan selama delapan belas tahun (dari tahun 1975 sampai dengan 1993), kemudian disusul dengan perubahan kurikulum yang sesuai dengan SK Menteri Agama No. 372 Tahun 1993 untuk madrasah tingkat Ibtidaiyah dan Tsanawiyah, dan SK Menteri Agama 373 dan 374 untuk Madrasah Aliyah dan Madrasah Aliyah Keagamaan.

Dengan terbitnya UU SPN No. 2 Tahun 1989, madrasah dianggap sebagai sekolah umum yang berciri khas Islam sedang kurikulumnya untuk bidang studi umum sama dengan kurikulum sekolah plus agama. Pengakuan terhadap madrasah sebagai sekolah umum secara utuh sudah mulai tampak di kalangan masyarakat. Walaupun begitu, para praktisi pendidikan Islam berat melakukan penyesuaian karena selama ini madrasah memakai kurikulum sendiri, sehingga terkadang terlontar ungkapan yang kurang simpatik dari kalangan tertentu dengan menyatakan bahwa: "madrasah seperti kehilangan identitas". Dengan lahirnya UU SPN No. 20 Tahun 2003, kedudukan madrasah lebih bertambah kuat, karena undangundang tersebut jelas memberi peluang yang sama kepada madrasah sebagai sekolah umum berciri khas Islam untuk mendapat pengakuan, penghargaan, dan hilangnya atau tidak terjadi anggapan diskriminatif di mata pemerintah. Pengakuan kepada madrasah yang menjadikannya sebagai subsistem pendidikan dalam sistem pendidikan nasional mempunyai berbagai konsekuensi, antara lain menjadi keharusan pola pembinaan madrasah mengikuti satu ukuran yang mengacu kepada sekolah pemerintah, artinya madrasah mengikuti kurikulum nasional, ikut serta dalam ujian negara, dan berbagai peraturan yang berlaku di Departemen Pendidikan Nasional.

Perhatian pemerintah terhadap madrasah yang dibinanya tumbuh secara meyakinkan. Pada beberapa propinsi termasuk di Sulawesi Selatan, dibangun Madrasah Model untuk dijadikan madrasah percontohan, baik pada level Ibtidaiyah, Tsanawiyah maupun Aliyah. Madrasah Model ini mendapat bantuan pembiayaan dari World Bank dan Asian Development Bank (ADB) sebagai hasil kerja sama dengan pemerintah Indonesia. Bantuan tersebut dialirkan ke berbagai madrasah untuk memperbaiki gedung dan memberikan dukungan fasilitas lainnya, seperti pengadaan laboratorium IPA, Bahasa, dan Perpustakaan serta peningkatan kualitas tenaga pendidik melalui pemberian beasiswa untuk melanjutkan pendidikan ke jenjang yang lebih tinggi sesuai bidang keahlian masing-masing. 
Sedangkan Madrasah swasta yang terbilang unggul dapat dihitung jari, itu juga karena di-back up oleh yayasan swasta yang sudah mapan, baik dari sisi usia maupun tingkat kematangan penanganan pendidikan madrasah, misalnya Madrasah Aliyah Insan Cendekia Serpong dan Madrasah Aliyah Insan Cendekia Gorontalo yang dulu dibina oleh BPPT pada masa Presiden B. J. Habibi dan sekarang dialihkan kepada Depag. Kedua madrasah ini malah dijadikan model percontohan dalam pengembangan pengajaran ilmu pengetahuan dan teknologi bagi lembaga pendidikan lainnya. ${ }^{8}$

\section{MODEL KEBIJAKAN PEMERINTAH MEMBANGUN MUTU DAN PENGARUHNYA TERHADAP PEMBINAAN MADRASAH SWASTA}

Upaya-upaya pemerintah dalam melakukan pembinaan terhadap madrasah dapat dilihat dalam beberapa model madrasah berikut ini:

\section{Madrasah Negeri dan Swasta}

Secara formal, madrasah di Indonesia hanya terdiri dari madrasah negeri dan swasta. Namun, pada awalnya, seluruh madrasah di lingkungan Departemen Agama adalah madrasah swasta yang diprakarsai pendiriannya oleh masyarakat Islam setempat. Madrasah negeri pada umumnya berasal dari madrasah swasta yang dinegerikan. Kelahiran madrasah di Indonesia diawali ketika Departemen Agama didirikan, di mana salah satu bagian pendidikan adalah mengadakan suatu pilot project sekolah yang akan menjadi contoh bagi orang-orang atau organisasi yang ingin mendirikan sekolah secara partikelir (swasta). Tugas ini mengandung maksud sekolah agama milik pemerintah diperlukan sebagai panutan atau contoh bagi pihak swasta dalam mengelola pendidikan agama. Pendirian madrasah negeri merupakan sisi lain. dari bentuk bantuan dan pembinaan terhadap madrasah swasta. Adapun Madrasah Aliyah Insan Cendekia yang ada di Gorontalo dan Serpong, baru saja berdiri beberapa tahun lalu, karena ditunjang dana dan fasilitas yang memadai sehingga pembinaannya sangat maju, sementara yang dipresentasikan dalam penelitian adalah madrasah swasta sebelumnya.

Menurut Rahim ${ }^{9}$, madrasah ibtidaiyah negeri sebagian besar berasal dari madrasah-madrasah yang semula diasuh oleh Pemerintah Daerah di beberapa daerah seperti Aceh, Lampung, dan Surakarta. Sejak tahun 1946 ada 205 Sekolah Rendah Islam (sebutan untuk Madrasah Ibtidaiyah) ${ }^{10}$ yang diasuh oleh Pemerintah Daerah Aceh yang dengan kesepakatan Menteri Agama No. I Tahun 1959, pengasuhan dan pemeliharaanya 
diserahkan kepada Kementrian Agama dan namanya dirubah menjadi Sekolah Rakyat Islam. Kemudian melalui Keputusan Menteri Agama No. 104 tahun 1962 diubah namanya menjadi Madrasah Ibtidaiyah Negeri (MIN). Madrasah Tsanawiyah seperti halnya Madrasah Ibtidaiyah juga kebanyakan berstatus swasta. Madrasah Tsanawiyah Negeri baru mulai didirikan pada tahun 1967.

\section{Madrasah Model}

Madrasah Model adalah madrasah konvensional yang dikelola secara khusus untuk menjadi teladan atau model madrasah yang berkualitas, sehingga dapat menjadi contoh bagi madrasah negeri dan swasta di sekitarnya dan dapat juga meningkatkan kualitas madrasah lain di sekitarnya. Maksud utama pendirian madrasah model adalah meningkatkan kualitas bidang sains dan matematika, di samping manajemen, sarana dan prasana belajar.

\section{Madrasah Terpadu}

Madrasah Terpadu merupakan sebuah model madrasah yang berbasis pada konsep keterpaduan dengan melokalisasi madrasah di semua tingkatan, MIN, MTsN, dan MAN berada dalam satu lokasi dan berada di bawah sebuah manajemen sekolah. Seluruh aspek pendidikan, baik kurikulum, proses belajar mengajar, perpustakaan, guru, fasilitas pendidikan dapat dipadukan sebagai satu kesatuan yang terintegrasi.

\section{Madrasah Aliyah Keagamaan}

Madrasah Aliyah Keagamaan adalah Madrasah Aliyah Program Khusus dengan fokus pengajaran pendidikan agama. Program ini merupakan antisipasi terhadap menurunnya kemampuan bidang agama pada lulusan Madrasah Aliyah setelah mereka berubah menjadi madrasah dengan beban kurikulum 70\% umum dan 30\% agama (SKB 3 Menteri 1974). Apalagi ketika UU Sisdiknas No. 2 Tahun 1989 yang menyamakan kurikulum sekolah dengan madrasah, yang membedakan hanya jumlah jam pelajaran agama yang menjadi ciri khas. Efek penyamaan kurikulum adalah bertambahnya beban yang harus dipikul oleh madrasah.

\section{Madrasah Aliyah Program Keterampilan}

Madrasah Aliyah Program Keterampilan adalah Madrasah Aliyah yang diberi tambahan program ekstra kurikuler dalam berbagai bidang keterampilan yang terstruktur. Tujuan program ini adalah untuk memberi bekal life skill yang tidak mampu melanjutkan pendidikan hingga ke jenjang perguruan tinggi. Sedangkan visi dari madrasah ini adalah menyiapkan SDM yang terampil, mandiri, religius, dan berwawasan ke depan. 
Siswa yang menjadi sasaran dalam program keterampilan ini adalah: mereka yang tidak memiliki kemampuan ekonomi yang memadai sehingga tidak mampu melanjutkan pendidikan ke jenjang yang lebih tinggi. Madrasah program keterampilan ini dimulai pada tahun 1989 dengan bantuan dari IINDP/UNESCO di tiga madrasah di Jawa sebagai pilot project. Program keterampilannya terdiri atas keterampilan menjahit, reparasi radio/tv, dan otomotif. Ketiga MAN tersebut adalah MAN Garut Jawa Barat, MAN Kendal Jawa Tengah, dan MAN Jember Jawa Timur, menyusul MAN Medan (Suamtera Utara), MAN Bukit Tinggi (Sumatera Barat), MAN Praya (NTB), MAN Banjarmasin (Kalsel), dan MAN Watampone (Sulawesi Selatan).

Pembina madrasah pada daerah penelitian mengakui bahwa usaha pemerintah cukup untuk meningkatkan madrasah dengan menciptakan model-model percontohan, tetapi madrasah swasta yang hanya berbasis uluran tangan masyarakat setempat, sementara iming-iming bantuan yang disebutkan dalam beberapa surat kebijakan ternyata tidak ada yang sampai kepada madrasah swasta. Madrasah swasta masih merasakan adanya diskriminasi.

\section{HASIL IMPLEMENTASI KEBIJAKAN PENDIDIKAN PADA MADRA- SAH SWASTA}

Sebagaimana telah dijelaskan terdahulu bahwa SK 3 Menteri dalam makna kebijakan melegitimasi kehadiran madrasah setaraf dengan sekolah, meskipun dalam penerapannya mengesankan adanya diskriminasi, yaitu tidak semua diktum dalam kebijakan tersebut dapat terealisasi dan menjangkau semua aspek bagi pembinaan madrasah swasta seperti keinginan $\mathrm{SKB}$, dan yang paling merasakan manfaatnya adalah madrasah negeri, karena seluruh fasilitas penunjang terpenuhi. Dalam penerapan SKB 3 Menteri berkaitan dengan peningkatan mutu madrasah, sampai lahirnya SKB 2 Menteri, No. 2099/U/1984 tentang pengaturan pembakuan kurikulum pada sekolah umum dan kurikulum madrasah, menjadikan madrasah swasta dengan seluruh keterbatasannya diharuskan melakukan perubahan dan menysuaikan diri dengan keinginan SKB tersebut.

Kenyataan yang terjadi bahwa dalam hal perbantuan, baik berupa fasilitas penunjang pendidikan maupun ketenagaan, termasuk abituren madrasah ketika memilih perguruan tinggi untuk melanjutkan pelajaran, seperti memilih peluang kerja di sebuah instansi, mereka merasakan adanya diskriminasi. Hal ini merupakan tantangan bagi madrasah swasta, sebab bagaimanapun juga madrasah adalah lembaga pendidikan yang sudah diakui dan telah melahirkan banyak abituren. Hal ini menjadi salah satu 
sebab Munawir Syazali sebagai Menteri Agama dengan sebuah kebijakan mendirikan madrasah percontohan seperti Madrasah Program Khusus, Madrasah Model, Madrasah Keterampilan, dan Madrasah Terpadu.

\section{BERBAGAI PERSOALAN YANG DIHADAPI OLEH MADRASAH SWASTA}

Khusus terkait dengan perkembangan madrasah swasta, setidaknya ada dua persoalan mendasar yang dapat diidentifikasi, sebagai berikut:

Pertama, pergantian kepemimpinan negara yang melahirkan reformasi total menyebabkan terjadinya pergeseran kebijakan dari sistem sentralistik menjadi desentralistik, sekaligus memunculkan UU No. 32 Tahun 2004 tentang Pemerintahan Daerah, dan UU No. 33 Tahun 2004 tentang Perimbangan Keuangan antara Pemerintah Pusat dan Daerah (kedua undang-undang ini adalah hasil amandemen terhadap undangundang sebelumnya, yaitu: UU No. 22 Tahun 1999 dan UU No. 33 Tahun 1999 yang sudah dinyatakan tidak berlaku). Kondisi ini cukup berpengaruh kepada Pendidikan Agama Islam, sebab semangat baru yang timbul dengan otonomi daerah akan memberikan kesempatan kepada seluruh masyarakat untuk berupaya mengelola sendiri kondisi dan kebutuhan daerahnya dalam semua aspek pengembangannya, tetapi beberapa kewenangan dalam berbagai bidang masih ditangani oleh pusat, seperti: bidang politik luar negeri, pertahanan keamanan, peradilan, moneter dan fiskal, serta bidang agama (lihat UU No. 32 Tahun 2004, ps 10 ayat (3). ${ }^{11}$

Dari sini lahir pendapat: 1) bahwa pendidikan agama yang diasuh Departemen Agama tidak diotonomkan. Hal ini menunjukkan bahwa Pendidikan di Departemen Agama dikategorikan sebagai bagian dari agama, bukan bagian dari sistem pendidikan nasional; 2) pendidikan yang dikelola Departemen Agama adalah bagian sistem pendidikan nasional, karena pendidikan diotonomkan. Seperti juga tentang perimbangan keuangan antara Pemerintah Pusat dan Daerah; walaupun bantuan keuangan negara porsinya akan lebih banyak diberikan kepada daerah sesuai dengan potensi dan kemampuan perekonomian daerah, tentu berbeda-beda di setiap daerah. Sementara peranan Daerah Propinsi sebagai daerah otonom juga sebagai wilayah admnistrasi lebih terbatas lagi. Kenyataan ini mengantar Departemen Agama dalam melakukan pembinaan madrasah dihadapkan kepada dua pilihan: a) tetap melakukan pembinaan madrasah secara sentralistik; dan b) menyerahkan pembinaan madrasah pada pemerintah daerah tingkat kabupaten/kota sebagai konsekuensi dari UU otonomi daerah di bidang pendidikan.

Hal-hal tersebut bukanlah merupakan sesuatu yang kebetulan, tetapi sebagai akibat terjadinya perubahan dalam sistem kenegaraan, yang tentu 
saja mempengaruhi seluruh sendi-sendi kehidupan berbangsa dan bernegara, tidak terkecuali bidang pendidikan. Bidang agama yang dinyatakan masih bersifat sentralistik menurut undang-undang, memberi makna bahwa penyelenggaraan pembinaan dan pengendalian madrasah sebagai institusi pendidikan ditangani oleh Departemen Agama secara terpusat, baik pendanaannya maupun penentuan jenis dan target program yang seharusnya dicapai pada masing-masing madrasah di berbagai tingkatannya. Sementara pelaksana dari kebijakan pusat adalah daerah. Mungkin kondisi ini terkesan menguntungkan, tetapi bila dipikir lebih jauh tenyata pilihan ini memberikan dampak yang kurang menguntungkan Departemen Agama, dengan beberapa alasan:

- madrasah hanya mendapat biaya pusat sedang bidang pendidikan sudah banyak didaerahkan (sesuai dengan UU RI No. 32 Tahun 2004 Bab III, ps. 13 (1) dan ps. 14 (1);

- madrasah menjadi bagian diri agama bukan bagian UU SPN. Kalau ini terjadi maka perhatian pada madrasah semakin tidak berarti bagi pembinaannya;

- dengan politik pusat, secara akademis madrasah akan mengalami gangguan yang tentu tidak menguntungkan;

- madrasah dengan pergantungannya ke pusat menyebabkan masyarakat menjadi kurang perduli kepada pembiayaan kebutuhan madrasah;

- pola birokrasi yang berbelit-belit semakin mempersulit pengembangan dan pembinaan madrasah.

Untuk memilih alternatif kedua boleh jadi dapat menguntungkan madrasah meskipun merugikan Departemen Agama, justru tugas-tugas keumatan menjadi berkurang kalau tidak dapat disebut kehilangan lahan yang selama ini menjadi garapannya. Pertama, madrasah menjadi kuat kedudukannnya sebagai bagian dari UU SPN, yang implikasinya bagi madrasah memiliki kesejajaran dengan sekolah umum dan mungkin diskriminasi sudah hilang. Kedua, para Kepala Sekolah dan guruguru akan lebih bebas mengembangkan diri dalam pengelolaan madrasah. Ketiga, suasana akademik akan lebih berkembang karena pengelolaan yang terprogram berkat partisipasi dari semua tenaga yang ada. Keempat, elemen masyarakat lebih dapat dimanfaatkan oleh pembina madrasah, baik Kepala Sekolah maupun guru-guru. Kelima, pembinaan administrasi akan berimbang dengan pengembangan kreativitas di bidang akademik. Dari siniakan lahir manusia-pekerja dan manusia-pemikir. ${ }^{12}$

Meskipun demikian, muncul kekhawatiran dari banyak pihak ketika madrasah dilimpahkan ke daerah pengelolaan dan pembinaannya, jangan sampai ciri khas madrasah tidak dapat dipertahankan justru pembi- 
naannya dilakukan oleh tenaga-tenaga yang kurang memahami "ruh" dari madrasah itu sendiri, malah mungkin pembina atau pengelola bukan berlatar belakang madrasah. Selain hal tersebut, otonomi daerah juga dapat memberikan kesempatan kepada madrasah berkiprah dalam pengembangan kemitraan secara bebas, dengan lembaga lain terkait dengan peningkatan kualitas atau mutu dalam berbagai aspeknya. ${ }^{13}$

Kedua, madrasah saat ini menghadapi pilihan yang tidak mudah, yakni antara memenuhi kebutuhan keagamaan (idealisme) dan kebutuhan dunia (pragmatisme). Di satu sisi, madrasah dituntut untuk bisa berfungsi meningkatkan pemahaman ilmu-ilmu keagamaan dan kemampuan mengamalkan ajaran Islam. Sementara di sisi lain, lembaga ini dituntut untuk menumbuhkan kemampuan peserta didik dalam memenuhi kebutuhan yang tidak seluruhnya dipecahkan melalui ilmu agama.

Sejak madrasah dikembangkan bersamaan dengan gerakan pembaharuan Islam di Indonesia, kurikulum madrasah terus berubah. Awalnya, kurikulum madrasah hanya terdiri atas ilmu-ilmu agama. Bentuk madrasah dikenal dengan madrasah diniyah yang telah ada sejak abad-abad pertama sejarah Islam di Timur Tengah. ${ }^{14}$

Perubahan kurikulum madrasah dari sekedar mengajarkan pendidikan agama lalu kemudian beralih pada pengajaran ilmu-ilmu umum disebabkan oleh kebutuhan masyarakat pengguna jasa madrasah. Munculnya gagasan islamisasi pengetahuan dan teknologi (IPTEK) telah memberi legitimasi teologis perubahan kurikulum. Dari sini mulai muncul gagasan tentang perlunya integrasi ilmu agama dalam IPTEK yang selama ini dikelompokkan ke dalam ilmu-ilmu sekuler. Muncul kemudian berbagai model madrasah terpadu yang mengintegrasikan ilmu umum dan ilmu agama ke dalam satuan kurikulum. ${ }^{15}$

Usaha penyatuan kedua sistem ilmu pada gilirannya hanya menambah persoalan madrasah menjadi semakin ruwet. Ini disebabkan oleh belum tersusunnya konsep integral yang ilmiah yang mampu mengatasi dikotomi ilmu umum dan ilmu agama. Integrasi kurikulum madrasah tidak lebih sebagai penggabungan dua sistem ilmu tanpa disertai dengan konsep yang jelas. Akibatnya, tujuan praktis untuk meningkatkan daya saing lulusan madrasah dengan sekolah umum menjadi sulit terpenuhi.

Dalam perkembangan selanjutnya, mengiringi kegiatan kependidikan secara umum, muncul juga berbagai macam usaha-usaha terkait dengan keinginan untuk memacu perkembangan peserta didik, yaitu:

Pertama, maraknya pendidikan dan kursus singkat sebagai alternatif. Hal ini berarti, selain problematika yang disebutkan di atas, tantangan lain 
yang dihadapi oleh lembaga pendidikan Islam seperti madrasah adalah persaingan dalam merebut perhatian publik. Dunia pendidikan saat ini sudah semakin ramai, di kota-kota besar banyak berdiri yayasan yang bergerak di sektor pendidikan dan pelatihan. Masing-masing yayasan menampilkan ciri tersendiri, mengikuti trend global yang menjadi kebutuhan masyarakat secara umum. Misalnya, dengan munculnya sekolahsekolah kejuruan yang di dalamnya diajarkan keterampilan, sesuai bidang keterampilan yang menjadi fokusnya. Sebut saja Sekolah Menengah Kejuruan (SMK) yang mengkhususkan diri pada bidang teknologi pembangunan, di dalamnya diajarkan berbagai pengetahuan dan keterampilan menyangkut penanganan mesin arus kuat (listrik), mesin arus lunak (electric), teknologi bangunan, teknologi informatika, teknik tata boga, akuntansi dan sebagainya. Pendirian sekolah-sekolah seperti itu semata-mata dimaksudkan untuk memenuhi kebutuhan pasar (konsumen) atau pengguna jasa.

Fenomena munculnya yayasan yang bergerak di bidang pendidikan dan pelatihan (kursus-kursus singkat) bukan lagi hanya di kota besar, melainkan juga sudah merambah ke daerah-daerah. Tampaknya, wadah seperti ini yang sekarang trend di masyarakat. Peminatnya cukup lumayan, terutama bagi yang sudah menyelesaikan studinya pada tingkat sekolah lanjutan atas (tamatan SMA). Mereka yang tidak melanjutkan pendidikannya ke Perguruan Tinggi memilih untuk mengikuti kursus singkat. Wadah ini bukan hanya sebagai alternatif, melainkan memang menjadi pilihan utama, karena dengan keterampilan yang dimiliki dapat dijadikan bekal untuk membuka lapangan pekerjaan (usaha sendiri) selepas mengikuti kursus. Atau minimal menjadi bahan kelengkapan persyaratan ketika mendaftar menjadi pegawai di lingkungan pemerintahan dan swasta.

Kenyataan di masyarakat seperti itu yang tidak terbaca dan terantisipasi oleh kebanyakan madrasah swasta, sehingga seakan-akan madrasah kehilangan semangat di tengah masyarakat atau istilah lainnya kehilangan pasar. Pengasuh madrasah larut dengan dirinya sendiri, tenggelam dalam kebiasaan tradisionalnya yang hanya memberikan suguhan pendidikan agama secara monoton. Sementara aspek pengetahuan (knowledge) dan keterampilan (skill) yang menjadi kebutuhan masyarakat (kebutuhan pasar) belum mendapat tempat di madrasah swasta.

Kedua, persaingan kualitas/mutu. Artinya, salah satu pertimbangan mengapa madrasah tidak masuk dalam kategori pilihan pertama masyarakat untuk menyekolahkan anak-anak dan keluarganya pada madrasah adalah karena persoalan kualitas atau mutu. Ada kecenderungan yang 
menjadi dasar pertimbangan dalam memilih sekolah, yaitu masyarakat mengaitkannya dengan knowledge and skill yang diajarkan di sekolah, karena persoalan tersebut terkait dengan pasar tenaga kerja dan masa depan.

Pendidikan saat ini harus dirancang untuk membekali peserta didik dengan kecakapan hidup yang secara integratif memadukan generik dan spesifik guna menghadapi dan memecahkan problema kehidupan. Pendidikan yang dimaksud adalah yang mampu mensinergikan antara mata pelajaran menjadi kecakapan yang dibutuhkan seseorang (pserta didik) dalam kehidupan di manapun berada terlepas dari latar belakang pekerjaannya atau apapun profesinya. Kecakapan hidup bukan hanya sekedar membekali keterampilan untuk bekerja, melainkan lebih luas dari itu. Setiap peserta didik dibekali dengan suatu nilai yang di dalamnya selain mengandung unsur teoretis keilmuan dan keterampilan juga dibekali dengan unsur pembentukan mentalitas kemanusiaan, seperti bagaimana membangun keberanian menjalani hidup, kreativitas, inovasi, dan sikap hidup yang terpuji.

Secara teoretis kecakapan hidup (life skill) adalah kecakapan yang dimiliki seseorang agar berani menghadapi problema hidup dan kehidupan dengan wajar, tanpa merasa tertekan, kemudian secara proaktif dan kreatif mencari serta menemukan solusi sehingga akhirnya mampu mengatasinya.

Kecakapan hidup dapat dikategorisasi ke dalam lima jenis, yaitu:

- Kecakapan mengenal diri (self awarness), yang biasa juga dikenal dengan kecakapan personal. Kecakapan personal ini mencakup penghayatan diri sebagai makhluk Tuhan, anggota masyarakat dan warga negara, serta menyadari dan mensyukuri kelebihan dan kekurangan yang dimiliki, sekaligus menjadikannya sebagai modal dalam meningkatkan dirinya sebagai individu yang bermanfaat bagi diri sendiri dan lingkungannya.

- Kecakapan berpikir rasional (thinking skill) yang meliputi kecakapan menggali dan menemukan informasi, kecakapan mengolah informasi dan mengambil keputusan, serta kecakapan memecahkan masalah secara kreatif (creative problem solving).

- Kecakapan sosial (social skill) atau kecakapan antar personal (interpersonal skill) mencakup kecakapan komunikasi dengan empati.

- Kecakapan akademik (academic skill) yang seringkali disebut dengan kemampuan berpikir mencakup, antara lain: kemampuan untuk mengidentifikasi variabel dan menjelaskan hubungan antara variabel tersebut, merumuskan hipotesis serta merancang dan melaksanakan. 
- Kecakapan vokasional (vocational skill) merupakan kecakapan yang dikaitkan dengan bidang pekerjaan tertentu yang terdapat di masyarakat. Kecakapan ini bersifat profesionalistik dengan mengarahkan kemampuan peserta didik untuk memiliki keterampilan-keterampilan khusus.

Untuk mendapatkan madrasah yang berkualitas, beberapa kelemahan yang ada dalam sistem pendidikan madrasah harus diatasi terlebih dahulu. Menurut Mastuhu16, kelemahan sistem pendidikan madrasah pada prinsipnya sama dengan sistem pendidikan nasional, yaitu: Pertama, mementingkan materi di atas metodologi. Pemberian materi terlalu banyak, tetapi tidak dibarengi dengan metodologi yang baik. Metodologi yang dikembangkan di madrasah-madrasah lebih banyak bersifat ceramah, sehingga meminimalisasi daya kreativitas peserta didik. Kedua, mementingkan memori di atas analisis dan dialog. Metode penghafalan sejauh ini masih menjadi alternatif utama dalam sistem pembelajaran pada madrasah. Pertanyaan-pertanyaan yang diajukan tidak diorientasikan untuk merangsang daya analisis peserta didik, tetapi lebih pada daya memorinya.

Di satu sisi, metode penghafalan memang baik untuk memperkenalkan peserta didik pada materi-materi pelajaran, tetapi sebaiknya diiringi dengan pancingan-pancingan yang merangsang daya pikirnya. Misalnya, si anak disuruh menghafal ayat tentang hubungan antara anak dan orangtua, lalu kemudian menyuruh si anak untuk mengontekstualisasikan dengan pengalaman yang terjadi di sekitarnya, baik pengalaman pribadinya maupun pengalaman orang-orang yang hidup di sekitamya. Ketiga, mementingkan pikiran vertikal/linier di atas lateral. Keempat, mementingkan penguatan otak kiri dibanding otak kanan. Kelima, materi pelajaran agama yang diberikan masih bersifat tradisional, belum menyentuh aspek rasional. Keenam, penekanan yang berlebihan pada ilmu sebagai produk formal, bukan pada proses metodologinya. Ketujuh, mementingkan orientasi proses "memiliki" ketimbang proses "menjadi". Oleh karena itu, perlu penerapan prinsip pendidikan berbasis luas yang tidak hanya berorientasi pada bidang akademik atau vokasional semata, tetapi juga memberikan bekal learning how to learn sekaligus learning how to unlearn, begitu pula tidak hanya belajar teori, tetapi juga mempraktekkannya untuk memecahkan problem kehidupan sehari-hari. ${ }^{17}$

Menurut Abdul Rahman Saleh, 18 ada empat hal yang sangat penting dilakukan dalam pembangunan pendidikan, yaitu: 1) lembaga pendidikan sebagai pusat pembudayaan nilai; 2) desentralisasi pendidikan; 3) demokratisasi pendidikan dan otonomi keilmuan;, serta 4) manajemen pendidikan yang efisien dan efektif. Selanjutnya dikemukakan bahwa apa yang terlihat sekarang memang belum seluruhnyan bisa dilaku- 
kan, karena bangsa ini sedang mengalami proses reformasi multidimensi, artinya sedang terjadi proses transformasi total menuju ke masyarakat baru yang terbuka dan demokratis. Sedangkan konsep perubahan pendidikan secara proporsional serta yang dicita-citakan masih dalam proses pencarian bentuk.

\section{OTONOMI DAERAH: HARAPAN DAN TANTANGAN}

Sebagai konsekuensi penyerahan wewenang tentang penyelenggaraan pendidikan dari pemerintah pusat seperti yang diatur dalam Undangundang No. 32 Tahun 2004 tentang Pemerintahan Daerah ${ }^{19}$ (Pasal 12 dan Pasal 14), pemerintah Kabupaten/Kota dituntut untuk mengelola program pendidikan dengan baik. Pemerintah daerah berkewajiban untuk membiayai penyelenggaraan pemerintahan dan pembangunan. Tilaar $^{20}$ dalam pernyataannya mempertegas bahwa desentralisasi pendidikan merupakan suatu keharusan, yang tidak dapat ditunda-tunda lagi. Tiga hal yang berkaitan dengan desentralisasi pendidikan, yaitu: 1) pembangunan masyarakat demokrasi; 2) pengembangan kapital sosial; dan 3) peningkatan daya saing bangsa. Pendidikan merupakan salah satu sektor bidang pembangunan yang didesentralisasikan. Dalam era otonomi dan desentralisasi dituntut adanya perubahan, penyesuaian, dan mugkin pembaruan dalam rangka mewujudkan pendidikan di mana sistem pendidikan terkait dengan kebutuhan otonom, kemandirian dan demokratisasi. Hal ini diharapkan dapat mengarahkan perhatian untuk mendorong semangat partisipasi masyarakat dengan tidak menghilangkan wawasan nasional.

Untuk melaksanakan sejumlah harapan seperti tersebut di atas, maka salah satu faktor yang paling penting dilakukan dalam penyelenggaraan pendidikan adalah perencanaan yang baik. Hal ini merupakan daya dukung yang positif dalam memecahkan berbagai masalah, tekait dengan tersedianya data yang menggambarkan keadaan yang sebenarnya (akurat) dan mutakhir. Sehubungan dengan perencanaan pendidikan paling tidak memenuhi prinsip-prinsip yang disebut SMART, ${ }^{21}$ yaitu sebagai berikut: specific (terperinci), measurable (terukur), achievable (terjangkau), reliable (dapat diandalkan), dan time bounded (berjangka waktu). Selain itu, dalam proses pembuatan perencanaan pendidikan harus mengacu kepada empat hal, yaitu: transparan, akuntabel, partisipatif, dan aspiratif (TAPA). Untuk memenuhi pelaksanaan perencanaan dengan berdasar pada prinsip-prinsip tersebut di atas, maka hal yang perlu dilakukan adalah melibatkan berbagai pihak dalam proses penyusunan perencanaan, mengkonsultasikan draf perencanaan kepada semua stakeholder (pemangku kepentingan), dan melaksanakan uji publik sebelum perencanaan ditetapkan dan disahkan untuk 
diimplementasikan. Adapun komponen perencanaan pendidikan, yaitu: perumusan visi dan misi, identifikasi isu-isu strategis, dan penentuan program-program strategis.

Harapan madrasah untuk mendapatkan perhatian dari pemerintah semakin besar ketika diberlakukan Undang-undang tentang Pemerintahan Daerah atau yang lebih populer dengan Desentralisasi/Otonomi Daerah (Otoda). Undang-undang tersebut menjadi tonggak baru munculnya ruang (space) yang lebih luas bagi daerah untuk menata potensi yang dimilikinya, termasuk pembinaan madrasah sebagai bahagian dari sistem pendidikan nasional. Adanya ruang tersebut setidaknya memberikan nuansa yang lebih bermakna, terutama pada efektivitas pelayanan dan pembinaan masyarakat. Artinya, kedekatan letak pemerintahan yang ada pada era otonomi dengan masyarakat yang dilayani minimal berimplikasi pada: 1) semakin responsifnya aparat pemerintahan terhadap aspirasi masyarakat; dan 2) meningkatnya kontrol masyarakat terhadap setiap gejala aspek pemerintahan.

Sebagai pendukung tulisan ini dikemukakan data madrasah negeri dan madrasah swasta yang telah diakreditasi, sebagai berikut:

Tabel 1

Jumlah Madrasah Negeri dan Swasta di Sulawesi Selatan

\begin{tabular}{lcc}
\hline \multicolumn{1}{c}{ Madrasah } & Madrasah Negeri & Madrasah Swasta \\
\hline Ibtidaiyah & 46 & 588 \\
Tsanawiyah & 36 & 475 \\
Aliyah & 28 & 169 \\
\hline \multicolumn{1}{c}{ Jumlah } & $\mathbf{1 1 0}$ & $\mathbf{1 . 2 3 2}$ \\
\hline
\end{tabular}

Bila dibandingkan jumlah madrasah tahun 1996/1997 dengan data EMIS 2001-2002, maka dapat dikatakan bahwa terdapat penurunan jumlah madrasah sebesar 83 buah, dengan rincian 1315 dikurangi 1232.

Tabel 2

Madrasah Swasta yang Terakreditasi

\begin{tabular}{lccccc}
\hline $\begin{array}{c}\text { Nama } \\
\text { Madrasah }\end{array}$ & $\begin{array}{c}\text { Tidak } \\
\text { Terdaftar }\end{array}$ & Terdaftar & Diakui & Disamakan & Jumlah \\
\hline Ibtidaiyah & 50 & 173 & 270 & 95 & $\mathbf{5 5 8}$ \\
Tsanawiyah & 41 & 239 & 153 & 42 & $\mathbf{4 7 5}$ \\
Aliyah & 7 & 110 & 38 & 14 & $\mathbf{1 6 9}$ \\
\hline
\end{tabular}

Data tersebut menunjukkan bahwa sejak diundangkannya UU SPN No. 2 Tahun 1989, usaha pemerintah (Departemen Agama) telah banyak 
melakukan upaya peningkatan mutu terutama madrasah swasta dengan melakukan akreditasi untuk semua madrasah di Sulawesi Selatan, seperti tertera dalam table di atas. Data ini terhitung 2001-2002, dalam masa tiga tahun (dari lahirnya UU SPN Tahun 1989 sampai dengan 2001 dilakukan pendataan melalui EMIS) ternyata belum dapat dilihat sebagai hal yang memadai karena masih banyaknya madrasah yang belum dipersamakan sebagai tingkat tertinggi dalam akreditasi untuk sama statusnya dengan lembaga lain.

\section{PENUTUP}

Berdasarkan uraian di atas, maka dapat ditarik beberapa kesimpulan, sebagai berikut:

> Implementasi kebijakan pada madrasah swasta seperti bantuan sarana dan prasarana, ketenagaan, fasilitas panunjang pembinaan madrasah tidak terpenuhi secara optimal, kecuali kurikulum terlaksana sesuai kemampuan setiap madrasah.

> Hasil implementasi kebijakan yang sentralistik kurang berpihak kepada madrasah swasta, meskipun menjanjikan bantuan dalam berbagai aspek untuk pembinaan madrasah swasta.

Kebijakan pendidikan, yang ada sebelum UUSPN No. 2 Tahun 1989, menjadikan masyarakat (stakeholder) memiliki ketergantungan ke pusat kebijakan, menyebabkan partisipasi masyarakat melemah, dan madrasah mengalami kemunduran.

\section{CATATAN AKHIR:}

1. Undang-undang SISDIKNAS, UU R.I. No. 20 Tahun 2003, Jakarta: Sinar Grafika, 2003.

2. Community Based Education merupakan kebijakan yang memberikan kekuasaan bagi masyarakat untuk ikut serta dalam pendidikan sesuai dengan kebutuhan masyarakat sekitar.

3. Husni Rahim, Madrasah dalam Politik Pendidikan di Indonesia, Jakarta: Logos, 2005, h. 38-40.

4. M. Irfan Islamy, Prinsip-prinsip Perumusan Kebijakan Negara, Jakarta: Bumi Aksara, 2001, h. 17.

5. Sugiyono, Metode Penelitian Administrasi, Bandung: Alfabeta, 2000, h. 8.

6. Budi Winarmo, Teori Kebijaksanaan Publik, Yogyakarta: Pusat Antar Universitas, Studi Sosial, UGM Yogyakarta, 1989, h. 3.

7. William M. Dunn, Analisis Kebijaksanaan Publik, Yogyakarta: Harindita, 2003, h. 58.

8. Jamaluddin, Mendiskusikan Kembali Eksistensi Madrasah, Jakarta: Logos Wacana Ilmu, 2003, h. 99. 
9. Husni Rahim, Madrasah dalam Politik Pendidikan di Indonesia, h. 161-162.

10. Dalam peraturan Menteri Agama No. 1 Tahun 1946 disebutkan bahwa jenjang pendidikan madrasah terdiri atas: a) Madrasah Tingkat Rendah, dengan lama belajar sekurang-kurangnya empat tahun dan berumur 6 sampai 15 tahun; b) Madrasah Lanjutan dengan masa belajar sekurang-kurangnya tiga tahun setelah tamat dari Madrasah Tingkat Rendah dan berumur 11 tahun ke atas. Peraturan ini kemudian disempurnakan dengan Peraturan Menteri Agama No. 7 Tahun 1952 yang berlaku untuk seluruh wilayah R.I. Dalam peraturan tersebut dinyatakan bahwa jenjang pendidikan madrasah adalah: a) Madrasah Rendah (sekarang Madrasah Ibtidaiyah) dengan masa belajar 6 tahun; b) Madrasah Lanjutan Tingkat Pertama (sekarang Madrasah Tsanawiyah), lama belajar 3 tahun setelah tamat Madrasah Ibtidaiyah; c) Madrasah Lanjutan Atas (sekarang Madrasah Aliyah), lama belajar 3 tahun setelah tamat dari Madrasah Tsanawiyah.

11. Undang-undang Pemerintahan Daerah 2004, UU RI No. 32 Tahun 2004, Jakarta: Sinar Grafika, 2005, h. 10-11.

12. Husni Rahim, Madrasah dalam Politik Pendidikan di Indonesia, h. 3-7.

13. Husni Rahim, Madrasah dalam Politik Pendidikan di Indonesia, h. 8.

14. Abdul Munir Mulkan, "Dilema Madrasah di Antara Dua Dunia", dalam Jamaluddin, Mendiskusikan Kembali Eksistensi Madrasah, Jakarta: Logos Wacana Ilmu, 2003, h. 4-5.

15. Ide perubahan IAIN dari model institut menjadi universitas (UIN) juga tidak terlepas dari logika ini. Ilmu-ilmu agama dipandang tidak menarik lagi untuk dijadikan "jualan". Pola epsitemologi masyarakat modern yang cenderung pragmatis dan meletakan dunia pendidikan sebagai modal untuk mendapatkan pekerjaan, memaksa IAIN sebagai lembaga keislaman berubah haluan dengan mengakomodasi studi-studi umum.

16. Mastuhu, Memberdayakan Sistem Pendidikan Islam, Jakarta: Logos Wacana Ilmu, 1999, h. 59.

17. Jim Bently, Learning Beyond the Classroom, Education for Changing World, London: Routledge Falmen, 2000, h. 59.

18. Abdul Rachman Shaleh, Paradigma Baru Pendidikan Nasional, Jakarta: Rineka Cipta, h. 57.

19. Undang-undang Pemerintahan Daerah 2004, UU R.I. No. 32 Tahun 2004, h. 1214.

20. H.A.R. Tilaar, Membenahi Pendidikan Nasional, Jakarta: Rineka Cipta, 2002, h. 20.

21. Managing Basic Education (USAID), Paket Lokakarya Pemetaan dan Perencanaan Pendidikan, US-Indonesia: Juni 2005, h. 8.

\section{DAFTAR PUSTAKA:}

Bently, Jim, Learning Beyond the Classroom, Education for Changing World, London: Routledge Falmen, 2000.

Dunn, William M., Analisis Kebijaksanaan Publik, Yogyakarta: Harindita, 2003.

Islamy, M. Irfan, Prinsip-prinsip Perumusan Kebijakan Negara, Jakarta: Bumi Aksara, 2001.

Jamaluddin, Mendiskusikan Kembali Eksistensi Madrasah, Jakarta: Logos Wacana Ilmu, 2003. 
Managing Basic Education (USAID), Paket Lokakarya Pemetaan dan Perencanaan Pendidikan, US-Indonesia: Juni 2005.

Mastuhu, Memberdayakan Sistem Pendidikan Islam, Jakarta: Logos Wacana Ilmu, 1999.

Mulkan, Abdul Munir, "Dilema Madrasah di Antara Dua Dunia", dalam Jamaluddin, Mendiskusikan Kembali Eksistensi Madrasah, Jakarta: Logos Wacana Ilmu, 2003.

Rahim, Husni, Madrasah dalam Politik Pendidikan di Indonesia, Jakarta: Logos, 2005.

Shaleh, Abdul Rachman, Paradigma Baru Pendidikan Nasional, Jakarta: Rineka Cipta, 2000.

Sugiyono, Metode Penelitian Administrasi, Bandung: Alfabeta, 2000.

Tilaar, H.A.R., Membenahi Pendidikan Nasional, Jakarta: Rineka Cipta, 2002.

Undang-undang Pemerintahan Daerah 2004, UU R.I. No. 32 Tahun 2004, Jakarta: Sinar Grafika, 2005.

Undang-Undang SISDIKNAS, UU R.I. No. 20 Tahun 2003, Jakarta: Sinar Grafika, 2003.

Winarmo, Budi, Teori Kebijaksanaan Publik, Yogyakarta: Pusat Antar Universitas, Studi Sosial, UGM Yogyakarta, 1989. 